
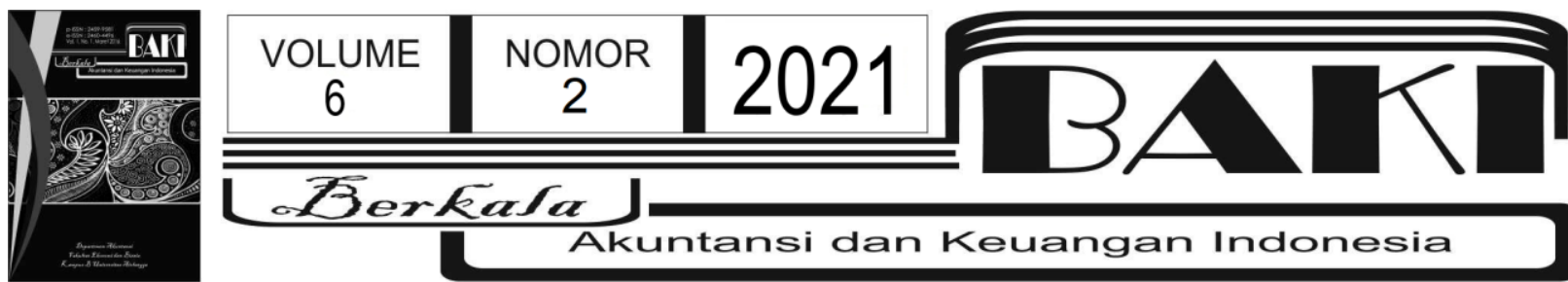

Lerkata

Akuntansi dan Keuangan Indonesia

\title{
THE EFFECT OF INCOME, SOCIALIZATION, TAXPAYER AWARENESS, AND TAX SANCTION ON THE COMPLIANCE OF LAND AND BUILDING TAX PAYMENT AT DUKUH PENGKOL
}

\section{PENGARUH PENGHASILAN, SOSIALISASI, KESADARAN WAJIB PAJAK, DAN SANKSI PERPAJAKAN TERHADAP KEPATUHAN PEMBAYARAN PAJAK BUMI DAN BANGUNAN DI DUKUH PENGKOL}

\author{
Oceania Andika Putri ${ }^{1 *}$ iD, Ismunawan ${ }^{2}$
}

\author{
${ }^{1}$ Program Akuntansi, Sekolah Tinggi Ilmu Ekonomi Surakarta \\ 2Program Akuntansi, Sekolah Tinggi IImu Ekonomi Surakarta \\ 1*Corresponding Author : oceaniaputri26@gmail.com, ${ }^{2}$ wanismu@ymail.com
}

\section{INFOARTIKEL ABSTRACT}

\section{Histori Artikel:}

Tanggal Masuk 18 Februari 2021

Revisi Diterima 15 April 2021

Tanggal Diterima 30 Agustus 2021

Tersedia Online 6 September 2021

Keywords: compliance, land and buildings, taxes, taxpayers.
This study aims to analyze the factors that influence compliance with land and building tax payments. The independent variables used are income, socialization, taxpayer awareness, and tax sanctions. This research was conducted on land and building taxpayers who are in Dukuh Pengkol. The method used in the collection of samples is purposive sampling with a sample size of 91 taxpayers. In collecting data using a questionnaire that is distributed using google form. The analytical tool used in this study is multiple linear regression and processed using SPPS Ver. 22.0. The results of this study indicate that, taxpayer income, taxpayer awareness, and tax sanctions have a significant and significant effect on compliance with land and building tax payments in DukuhPengkol. Meanwhile, tax socialization had no effect on compliance with land and building tax payments at Dukuh Pengkol.

Kata Kunci: bumi dan
bangunan, kepatuhan,
pajak, wajib pajak.

ABSTRAK

Penelitian ini memiliki tujuan untuk menganalisa faktor yang memberikan pengaruh pada kepatuhan pembayaran pajak bangunan 
serta bumi. Variabel bebas yang digunakan yakni penghasilan, sosisaliasi, kesadaran wajib pajak, dan perpajakan. Penelitian dilaksanakan terhadap wajib pajak bumi serta bangunan yang berada pada Dukuh Pengkol. Metode yang dipakai pada pengumupulan sampel yaitu purposive sampling memiliki jumlah sampel 91 wajib pajak. Dalam pengumpulan data memakai kuisioner yang disebar menggunakan google form. Alat analisa yang dipakai yakni regresi linier berganda diolah memakai SPPS Ver. 22.0. Hasil dari penelitian membuktikan jika, pendapatan wajib pajak, kesadaran wajib pajak, serta sanksi pepajakan memberi pengaruh signifikan pada kepatuhan pembayaran pajak bangunan serta bumi pada DukuhPengkol. Sementara sosialisasi perpajak tidak memberi pengaruh pada kepatuhan pembayaran pajak bangunan serta bumi di Dukuh Pengkol.

Berkala Akuntansi dan Keuangan Indonesia p-ISSN: 2459-9581; e-ISSN 2460-4496

DOI: 10.20473/baki.v6i2.25521

Open access under Creative Common Attribution-Non Commercial-Share A like 4.0 International Licence (CC-BY-NC-SA) @(1) @ (0)

\section{Pendahuluan}

PAD di Kabupaten Klaten dari Sektor Pajak Bumi serta Bangunan hingga Bulan Oktober 2020 mencapai Rp 29.000.000.000,00. Berdasarkan Kasubid Penetapan serta Pelayanan BKD Capaian pajak ini sudah melebihi target yang telah dipatok Pemerintah Kabupaten Klaten sebesar Rp 22.500.000.000,00, tetapi sampai akhir tahun 2020 bisa mencapai Rp 30.000.000.000,00. Meskipun target kepatuhan wajib pajak pada sektor Pajak Bangunan serta Bumi dapat dipenuhi pada Tingkat Kabupaten, dampak dari pandemi ke sektor ekonomi juga mempengaruhi kepatuhan wajib pajak bangunan serta bumi yang mempunyai nominal objek pajak yang cukup besar, mereka mengajukan penundaan pembayaran beralasan tidak dapat membayar tepat waktu.

Penerimaan pajak bangunan serta bumi Desa Wadunggetas pun di tahun 2020 hanya mencapai target $85 \%$ dari $100 \%$ dengan nominal target $\mathrm{Rp} 112.144 .000,000,00$ tetapi hanya menerima Rp 95.322.400,00. (Buku DHKP Desa Wadunggetas Tahun 2020). Hal itu dikarenakan banyak wajib pajak yang berdomisili di luar Desa Wadunggetas serta juga dikarenakan terdampak pandemi Covid. Dengan adanya pandemi Covid ini pemerintah Kabupaten Klaten menerapkan peraturan pengahapusan atau pembebasan denda yang berlaku mulai tanggal 1 Oktober 2020-31 Desember 2020. Diharapkan bagi wajib pajak yang masih mengajukan penangguhan pembayaran dapat membayarkan pajaknya tanpa dikenakan denda keterlambatan.

Dalam penelitian sebelumnya yakni penelitian yang dilakukan Arif Rahman (2018) mengungkapkan bahwa penghasilan dan kesadaran berpengaruh positif terhadap kepatuhan pembayaran pajak bumi serta bangunan. Dan dalam penelitian yang dilaksanakan oleh Widiyanti \& Prananditya (2018) mengungkapkan bahwa sosialisasi dan sanksi juga 
berpengaruh terhadap kepatuhan pembayaran pajak bumi serta bangunan. Perbedaan penelitian ini dan penelitian sebelumnya yakni dalam variabel sanksi. Di Kabupaten Klaten diberlakukan penghapusan denda administrasi akibat pandemic covid bagi wajib pajak yang tidak membayarkan pajaknya secara tepat waktu, pengapusan dilakukan mulai bulan Oktober hingga Desember 2020. Dan pada tahun 2020pula Kabupaten Klaten capaian pajak bumi serta bangunan melebihi target sedangkan di Desa Wadunggetas tidak dapat mencapai targetnya.

Penelitian dilaksanakan guna melihat faktor apa saja yang mepengaruhi kepatuhan pembayaran pajak bangunan serta bumi, mengingat pada Tahun 2020 Pemerintah Kabupaten Klaten dapat melebihi target pajak bumi dan bangunannya, tetapi di Desa Wadunggetas belum mencapai targetnya. Dengan kondisi yang demikian peneliti menggukan sampel populasi di Dukuh Pengkol, Desa Wadunggetas. Dari informasi yang saya dapatkan melalui pegawai kelurahan Desa, setiap tahunnya pajak bangunan serta bumi yang tak lunas sebanyak $15-20 \%$ yang disebabkan karena banyak hal. Manfaat penelitian ini guna melihat kepatuhan wajib pajak bangunan serta bumi dipengaruhi oleh faktor apa saja, sehingga dapat digunakan untuk acuan penarikan pajak bumi bangunan yang akan datang.

Kondisi pandemi covid seperti ini membuat keadaan ekonomi masyarakat bahkan negara tidak stabil, sehingga menjadikan pendapatan yang berkurang menjadi alasan wajib pajak tidak memenuhi kepatuhan wajib pajaknya. Dan tidak adanya sosialisasi terkait pajak bangunan serta bumi pada masyarakat, akhirnya kurang meningakatkan kesadaran wajib pajak yang mana kesadaran masyarakat untuk membayar kewajiban sebagai wajib pajak penting untuk mancapai target. Sehingga diharapkan setelah menulis artikel ini dapat mengetahui faktor yang menyebabkan kepatuhan pembayaran pajak bangunan serta bumi.

Tulisan ini dilanjutkan dengan memaparkan tinjauan pustaka, metodologi penelitian, lalu hasil dan pembahasan, serta kemudian simpulan, saran, dan keterbatasan akan menjadi penutup pada rangkaian tulisan ini.

\section{Tinjauan Pustaka}

\subsection{Teori Atribusi}

Teori atribusi pertama kalinya dikembangkan oleh Harrold Kelley di tahun 1958. Teori atribusi menjelaskan yaitu individu mencoba guna menentukan mengapakah seseorang melaksankaan suatu hal yang ingin dilakukannya. Dr. Samsuar (2019) mengatakan proses ini dilaksanakan guna mendapatkan jawaban mengenai mengapakah dan sebab terhadap tingkah laku individu lain maupun dirinya.

Purnaditya \& Rohman (2015) mengatakan perilaku ini dikarenakan faktor eskternal serta internal. Perilaku yang dimunculkan dengan cara internal yang tingkah laku yang ada di bawah kontrol seseorang. Dan perilaku yang dimunculkan dengan cara eksternal yakni perilaku yang 
dipengaruhi luar seseorang, berarti seseorang terpaksa melakukan perilaku sebab adanya pengaruh sosial dari orang lain. Alasan penulis menggunakan teori ini karena sesuai guna mengetahui faktor yang menjadikan kepatuhan seseorang untuk melunasi pajak. Teori ini menjelaskan sikap dan tingkah laku yang diakibatkan faktor eksternal serta internal.

\subsection{Pajak}

Berdasarkan Undang-Undang No. 16 Tahun 2009 Pajak yakni konstribusi wajib pada negara yang terutang badan ataupun seseorang yang memiliki sifat memaksa sesuai berdasar UU, dan tidak memperoleh timbal balik dengan langsung serta dipakai guna kebutuhan negara untuk sebanyak-banyaknya kesejahteraan masyarakat. Prof. Dr. Rochmat Soemitro dalam Mardiasmo (2019) menguraikan pajak yakni iuran yang diberikan masyarakat terhadap kas negara berdasar Undang-Undang tanpa memperoleh imbalan yang secara langsung bisa diterima masyarakat serta dipakai guna melunasi pengeluaran umum.

Berdasarkan pengertian tersebut bisa ditarik kesimpulan yakni, pajak merupakan sumbangan wajib dan memaksa yang dibayarkan masyarakat ke kas Negara yang tertuang pada Undang-Undang. Maka, potensi penerimaan pajak sangat penting bagi penunjang kesuksesan pembangunan di daerah. Penyelenggara pemerintah membutuhkan dana yang cukup besar demi kesejahteraan rakyat. Salah satu tipe pajak yang terdapat pada Indonesia ialah Pajak Bumi serta Bangunan yang mana hasilnya akan diserahkan kepada Pemerintah Daerah guna melaksanakan pembanguna di daerah masing-masing (Setyowati \& Yushita, 2017)

\subsection{Pajak Bumi serta Bangunan}

Dasar Hukum Pajak Bumi serta Bangunan yakni Undang-Undang Nomor 20 Tahun 2009 tentang Pajak Daerah dan Retribusi Daerah, yang memiliki arti Pajak Bumi serta Bangunan ialah pajak atas bumi dan/atau bangunan yang dimiliki, dikuasai, dan/atau dimanfaatkan oleh orang pribadi atau Badan, kecuali kawasan yang digunakan untuk kegiatan usaha perkebunan, perhutanan, dan pertambangan. Pajak bumi serta bangunan adalah salah satu sarana untuk mencerminkan gotong royong Negara dalam pembiayaan dan pembagunan nasional, oleh karenanya ketika memungut pajak bangunan serta bumi haruslah melihat asas kepastian hukum, kesederhanaan, keadilan, dan didukung sistem manajemen perpajakan. Sehingga mudah bagi wajib pajak untuk melunasi kewajiban perpajakannya. Tarif pajak bangunan serta bumi perdesaan serta perkotaan adalah 0,3\%. (Mardiasmo, 2019) Bumi dan bangunan dapat membawa manfaat social perekonomian yang lebih bagus untuk organisasi ataupun seseorang yang mempunyai manfaat darinya (Jati, 2016) 


\subsection{Kepatuhan Wajib Pajak}

Kepatuhan wajib pajak berarti perilaku atau tindakan wajib pajak yang mentaati aturanaturan yang telah ditetapkan didefinisikan untuk tidak dilanggar (Siregar \& Rahayu, 2019) .Indonesia menggunakan sistem self assessment yang mana kepatuhan melunasi kewajiban perpajakan merupakan aspek utamanya. Wajib pajak memiliki tanggung jawab untuk melunasi semua kewajiban perpajakan dengan tepat waktu serta akurat (Mardiasmo, 2016)

Wajib pajak yang mematuhi kewajiban perpajakan merupakan wajib pajak yang selalu membayar pajak selalu tepat waktu. Kepatuhan wajib pajak yakni hal penting, dikarenakan bila wajib pajak tak taat dapat mengakibatkan niatan lalai yang mana akan menyebabkan berkurangnya penerimaan pajak (Saputra, 2015), mengingat permasalahan pembayaran pajak merupakan sebuah permasalahan yang sensitif serta kompleks, sebab melibatkan keterlibatan individu guna memberi semua asetnya pada Negara.

\subsection{Penghasilan Wajib Pajak}

$\mathrm{KBBI}$, mengartikan penghasilan adalah perhitungan jumlah uang yang hendak diterima atau pendapatan merupakan hasil yang berupa uang dari pelaksanaan pekerjaan. Penghasilan setiap masyarakat berbeda-beda nominalnya, karena pekerjaaan mereka juga tidak sama. Ada yang berpenghasilan tinggi, terdapat juga yang berpenghasilan rendah. Berdasarkan BPS penggolongan pendapatan dibagi menjadi empat yakni : <Rp.1.500.000,00 yaitu rendah; dibawah Rp.1.500.000,00 - Rp 2.500.000,00 yakni sedang; Rp 2.500.000,00 - Rp 3.500.000,00/bulan yakni tinggi; >Rp 3.5000.000,00/bulan yakni sangatlah tinggi.

Kementrian Sosial serta Perum Bulog memberikan program bantuan sosial beras bagi keluarga penerima PKH se-Indonesia, salah satunya keluarga petani yang terdampak wabah Corona. Setiap keluarga mendapatkan $15 \mathrm{~kg}$ beras kualitas medium. Pemerintah Indonesia juga melaksanakan program JKN -KIS yang dikelola BPJS yang mewajibkan seluruh warga Indonesia menjadi peserta JKN-KIS salah satunya WNA yang telah bekerja pada Indonesia setidaknya 6 bulan serta sudah membayar iuran kepesertaan (bpjs-kesehatan.go.id).

Faktor ekonomi sangatlah memberi pengaruh untuk pelaksanaan kewajiban perpajakan. Masyarakat yang tidak berpenghasilan / memiliki penghasilan sedikit akan sulit ketika melunasi pajak. la lebih mementingkan kebutuhan rumah tangga sebelum melunasi pajak (beritasatumedia.com). Isawati (2017) mengatakan pemungutan pajak harus memperhatikan tingkat potensi penghasilan wajib pajak untuk melunasi pajak, oleh sebabnya pajak haruslah dipungut dengan tepat waktu, yakni saat wajib pajak memiliki uang. Dalam penelitian Khoiroh \& Purwanto (2017) varibel penghasilan mempengaruhi kepatuhan pembayaan pajak bumi serta bangunan dimana banyak sedikitnya penghasilan yang dimiliki seseorang akan berpengaruh terhadap pembayaran pajaknya. 


\subsection{Sosialisasi Perpajakan}

Sosialisasi dalam perpajakan merupakan proses pembelajaran ke wajib pajak supaya melihat terkait perpajakan. Sosialisasi perpajakan menjadi hal yang utama untuk upaya peningkatan kepatuhan pembayaran pajak, sosialisasi bisa dilakukan dengan cara pendekatan melalui penyuluhan atau seminar agar masyarakat paham apa itu pajak (Khoiroh \& Purwanto, 2017). Karena masyarakat memerlukan sosialisasi yang rinci dan langsung, dengan demikian akan tepat sasaran supaya semua masyarakat merasakanya. Oleh sebab itu diperlukan sosialisasi perpajakan yang baik guna menimbulkan pengertian yang benar tentang prosedur dan tata cara perpajakan (Widiyanti \& Prananditya, 2018).

Informasi mengenai pajak bumi dan bangunan bisa dilaksanakan lewat media cetak dan elektronik, misalnya tv, radio, spanduk, poster (Khoiroh \& Purwanto, 2017) Dari informasi yang saya dapatkan melalui pegawai Kelurahan desa Wadunggetas, penarikan pajak bumi bangunan dilaksanakan dengan cara door to door melalui Ketua RT masing-masing. Khoiroh \& Purwanto (2017) mengatakan Pengetahuan dan pemahaman pembayaran pajak tak akan dilihat rakyat jika tidak ada pembinaan dan informasi melalui pemerintah, sehingga sosialisasi perpajakan menjadi hal yang penting untuk memupuk pemahaman mereka mengenai pajak.

\subsection{Kesadaran Wajib Pajak}

Kesadaran wajib pajak yakni kesediaan dari diri wajib pajak secara sukarela guna melakukan dan mematuhi peraturan perpajakan yang berlaku (Rahman, 2018) Salah satu karakteristik dari negara maju yakni ketika kesadaran rakyat akan pajak tinggi. Pembayaran pajak tidak hanya bersifat sukarela, tetapi pembayaran pajak merupakan syarat kewajiban kenegaraan sebagai warga negara guna menciptakan ekonomi nasional. Kesadaran perpajakan masyarakat sampai saat ini belum sampai ke target yang diinginkan mencapai tingkat yang diharapkan. Secara umum masyarakat masih memiliki kepercayaan yang minim dengan adanya pajak, sebab beban pajak yang berat, pembayaran seringkali sulit, dan masyarakat tidak mengetahui bagaimana cara menghitung dan melaporkan pajak. (pajak.go.id).

Wajib pajak yang mempunyai kesadaran perpajakan yang tinggi tidak akan menilai membayar pajak sebagai beban (Juwiyanti, 2017). Pembayaran pajak bangunan serta bumi dilaksanakan paling lambat enam bulan sesudah wajib pajak wajib pajak mendapatkan SPT, contoh apabila wajib pajak menerima SPT Bulan Maret, jatuh tempo pembayarannya yakni Bulan Agustus (Mardiasmo, 2019) dan apabila ada perubahan harta dan kekayaaan, wajib pajak harus segera lapor kepada pegawai pemungut pajak di kelurahan.

\subsection{Sanksi Perpajakan}

Sanksi perpajakan merupakan alat kontrol agar wajib pajak tetap memenuhi kewajiban perpajakan karena adanya kerugian yang akan diperoleh wajib pajak, jika tidak membayar pajak maka otomatis akan membuatnya wajib pajak harus memikirkan jika tidak ingin 
memenuhi kewajiban pajak (Siregar \& Rahayu, 2019) Besarnya tarif sanksi administrasi adalah 2\% per bulan dimana ketika jatuh tempo pajak terutang tidak / kurang dibayar (Rahayu, 2019). Menurut Khoiroh \& Purwanto (2017) dalam penelitiannya menyatakan bahwa sanksi pajak mempengaruhi ketaatan seseorang untuk melunasi pajak bangunan serta bumi, dimana sanksi administrasi dan pidana menjadikan masyarakat patuh dalam membayar pajak, karena menurut masyarakat membayar denda akan membut semakin rugi. Namun dalam kenyataannya walaupun sudah ada sanksi wajib pajak masih sering tidak membayar kewajiban pajak. Hal tersebut dapat disebabkan misal karena adanya faktor penguat laiinnya seperti tekanan dari atasan (Prananjaya \& Narsa, 2019).

\subsection{Hipotesis Penelitian}

\subsubsection{Pengaruh Penghasilan Wajib Pajak pada Kepatuhan Pembayaran Pajak Bumi serta Bangunan.}

Isawati (2017) mengatakan Pemungutan pajak harus memperhatikan tingkat potensi penghasilan wajib pajak untuk melunasi pajak, oleh sebabnya pajak haruslah dipungut dengan tepat waktu, yakni saat wajib pajak memiliki uang. Apabila wajib pajak tak mempunyai uang maka tidak bisa memenuhi kepatuhan wajib pajaknya, mengingat pendapatan atau kemapuan setiap wajib pajak berbeda-beda. Hal ini didukung oleh penelitan dari Khoiroh \& Purwanto (2017) yang menyimpulkan Penghasilan Wajib Pajak memberi pengaruh pada Kepatuhan Pembayaran Pajak Bumi serta Bangunan. Berdasarkan pemikiran tersebut, hipotesis yang diajukan yakni:

\section{$H_{1}$ : Penghasilan wajib pajak memberi pengaruh positif signifikan pada kepatuhan pembayaran pajak bumi serta bangunan.}

2.9.2. Pengaruh Sosialisasi Perpajakan pada Kepatuhan Pembayaran Pajak Bumi serta Bangunan.

Khoiroh \& Purwanto (2017) mengatakan sosialisasi perpajakan bertujuan agar masyarakat mengetahui dan memahami norma dalam perpajakan dan pentingnya pajak bagi negara dan masyarakat. Perpajakan mempunyai aturan yang sesuai dengan hukum, apabila tidak taat pada aturat itu akan dijatuhi sanksi. Sosialisasi yang dilaksanakan adalah memberi pengetahuan pada masyarakat mengenai perpajakan dan informasi aturan pemerintahan terkait pajak. Hal itu dapat dilaksanakan dengan melakukan pendekatan langsung pada rakyat lewat seminar terkait pajak, mengingat minimnya sosialisasi perpajakan yang disampaikan pada rakyat. Hal itu sesuai dengan penelitian dari Widiyanti \& Prananditya (2018) yang menyimpulkan Sosialisasi Perpajakan memberi pengaruh pada Kepatuhan Pembayaran Pajak Bumi serta Bangunan. Berdasar pemikiran ini, hipotesis yang dituliskan yakni :

\section{$\mathrm{H}_{2}$ : Sosialisasi perpajakan memberi pengaruh positif signifikan pada kepatuhan pembayaran pajak bumi serta bangunan.}


2.9.3. Pengaruh Kesadaran Wajib Pajak pada Kepatuhan Pembayaran Pajak Bumi serta Bangunan.

Juwiyanti (2017) mengatakan Wajib pajak yang mempunyai kesadaran perpajakan yang tinggi tidak akan menilai membayar pajak sebagai beban. Sehingga bertambah tinggi kesadaran wajib pajak guna patuh pada aturan perpajakan, kepatuhan pembayaran pajak bangunan serta bumi akan semakin bertambah. Hal ini didukung oleh penelitian dari Arif Rahman (2018) yang menyimpulkan Kesadaran Wajib Pajak memberi pengaruh atas Kepatuhan Pembayaran Pajak Bumi serta Bangunan. Berdasar pemikiran itu, hipotesis yang diajukan yakni:

$\mathbf{H}_{3}$ : Kesadaran wajib pajak memberi pengaruh positif signifikan pada kepatuhan pembayaran pajak bumi serta bangunan.

2.9.4. Pengaruh Sanksi Perpajakan pada Kepatuhan Pembayaran Pajak Bumi serta Bangunan.

Khoiroh \& Purwanto (2017) mengatakan sanksi pajak mempengaruhi ketaatan seseorang untuk melunasi pajak bangunan serta bumi, dimana sanksi administrasi dan pidana menjadikan masyarakat patuh dalam membayar pajak, karena menurut masyarakat membayar denda akan membut semakin rugi. Tetapi terdapatnya perhatian yang minim mengenai hukuman ini akan menjadikan wajib pajak kurang patuh untuk memenuhi kewajiban pajak bumi serta bangunnnya Hal ini didukung oleh peneltian dari Siregar \& Rahayu (2019) yang menyimpulkan Sanksi Perpajakan Memberi pengaruh pada Kepatuhan Pembayaran Pajak Bumi serta Bangunan. Berdasarkan pemikiran itu, hipotesis yang dituliskan yakni :

$\mathrm{H}_{4}$ : Sanksi perpajakan berpengaruh positif dan signifikan terhadap kepatuhan pembayaran pajak bumi dan bangunan.

\section{Metodologi Penelitian}

\subsection{Jenis Data}

Penelitian memakai jenis data primer, yang mana metode pengumpulan data didapatkan dari pembagian kuisioner ke responden yaitu wajib pajak bangunan serta bumi yang ada pada Dukuh Pengkol. Kuisioner tersebut berupa pernyataan yang dilengkapi dengan alternatif lima jawaban. Data sekunder diperoleh dari buku "DHKP Pajak Bumi serta Bangunan Tahun 2020 Desa Wadunggetas."

\subsection{Populasi serta Sampel}

Populasi yang dipakai di penelitian yakni wajib pajak bumi serta bangunan pada Dukuh Pengkol. Teknik sampel memakai metode purposive sampling yang mana cara pemilihan sampel menggunakan kriteria. Sampel penelitian dipilih dari populasi wajib pajak bangunan serta bumi pada Dukuh Pengkol memiliki kriteria yakni: 
Tabel 3.1.

\section{Proses Pemilihan Sampel}

No Kriteria

1 Wajib pajak bangunan serta bumi yang ada pada Dukuh Pengkol tahun 2020

Jumlah

173

142

Dukuh Pengkol

3 Wajib pajak yang memiliki objek pajak terutang $>$ Rp 50.000,00

91

Jumlah Akhir

Sumber: Buku DHKP Desa Wadunggetas tahun 2020

\subsection{Definisi Variabel dan Pengukuran Variabel}

Khoiroh \& Purwanto (2017) menyatakan dalam variabel kepatuhan terdapat beberapa indikator, yaitu: Wajib pajak yang taat tidak akan lalai dalam melunasi pajaknya, Wajib pajak yang taat akan mengikuti aturan perpajakan yang berlaku, Wajib pajak yang patuh akan membayarkan pajaknya secara tepat waktu.

Khoiroh \& Purwanto (2017) menyatakan dalam variabel penghasilan wajib terdapat beberapa indikator, yaitu: Banyak sedikitnya penghasilan akan berpengaruh terhadap kompetensi individu untuk melunasi pajak, Masyarakat yang memiliki penghasilan cukup dalam memenuhi tuntutan primer saja, akan kesulitan bila harus mencukupi kebutuhan yang lain yang lebih besar, Pada saat penghasilan meningkat dan kebutuhan primer berkurang, maka uang akan dialokasikan ke biaya pendidikan, kesehatan, dan lainnya, Penghasilan yang dihasilkan atau oleh individu tak hanya uang dari hasil kerja pokok, tetapi dapat berbentuk sewa, barang, investasi yang didapatkan melalui kerja sampingan.

Khoiroh \& Purwanto (2017) menyatakan dalam variabel sosialisasi terdapat beberapa indikator, yaitu: Sosialisasi perpajakan dapat dilakukan melalui media cetak dan elektronik seperti tv, radio, poster, spanduk, Sosialisasi perpajakan dapat dilakukan dengan pendekatan secara langsung oleh pegawai kelurahan kepada masyarakat melalui seminar, Adanya sosialisasi perpajakan diharapkan bisa memberi stimulus baik supaya masyarakat bersedia melunasi pajak.

Juwiyanti (2017) menyatakan dalam variabel kesadaran terdapat beberapa indikator yaitu: Wajib pajak yang taat sadar bahwa melunasi pajak merupakan kewajiban masyarakat Indonesia, Wajib pajak membayarkan pajaknya dengan waktu yang tepat, Bagi wajib pajak melunasi pajak bukan suatu beban, Wajib pajak melaporkan ketika ada perubahan harta kekayaannya.

Khoiroh \& Purwanto (2017) menyatakan dalam variable sanksi terdapat beberapa indikator, yaitu: Penegakan sanksi pajak dibuat guna menciptakan ketaatan wajib pajak guna 
memenuhi pajak, Sanksi pajak bumi bangunan yaitu sebesar dua persen, Sanksi diberikan apabila pembayaran pajak melebihi jatuh tempo dan melakukan pemalsuan SPT.

\subsection{Teknik Analisis Data}

\subsubsection{Uji Validitas}

Uji ini mempunyai tujuan guna mengetahui valid atau tidak sebuah suatu pertanyaan. Kuisioner dinyatakan tepat apabila pertanyaan dalam kuisioner dapat mengugkapkan suatu hal yang diukur dari kuisioner itu. Guna mengetahui validitas dari kuisioner dapat memakai hubungan diantara setiap nilai, secara memperhatikan bila $r$ hitung $>r$ tabel serta positif, artinya nilai itu tepat dan bila hitung $<r$ tabel, artinya nilai itu tak tepat (Ghozali, 2015).

\subsubsection{Uji Reliabilitas}

Uji ini memiliki tujuan guna mengetahui konsisten atau tidak jawaban individu pada item pertanyaan di sebuah kuisioner. Sebuah kuisioner dinyatakan reiabel ketika jawaban responden pada pertanyaan konsisten. Kriteria pada uji reliabel ini menggunakan teknik Crobbach's Alpha yang mana sebuah kuisioner dinyatakan Reliabel bila Nilai Crobbach's Alpha $>0,60$ (Nurtantiono, 2020).

\subsubsection{Uji Asumsi Klasik}

\section{Uji Normalitas}

Uji ini mempunyai tujuan guna melihat normal tidaknya distribusi data. Penggunaan uji normalitas ini dikarenakan pada analisis statitik parametik, asumsi atas data tersebut adalah harus terdistribusi secara normal. Dilihat uji $F$ serta $t$ menunjukkan jika nilai residual berdistribusi normal. Bila asumsi tidak dipatuhi, uji statistic tak sah bagi jumlah sample sedikit. Penelitian memakai uji Kolmogorov-Smirnov yaitu jika angka pada sig $\geq 0,05$ berarti data memiliki distribusi normal, serta bila angka pada sig $\leq 0,05$ data memiliki distribusi tak normal (Ghozali, 2015).

\section{Uji Heteroskedastisitas}

Uji heterokedatisitas yaitu pengujian yang memiliki tujuan guna melihat apakah pada model regresi ada perbedaan varians antar pengamatan. Bila variance dari residu antar pengamatan stabil, disebub Homoskedastisitas, sebaliknya bila variance dari residual tidak sama dinamakan Heterokedastisitas. Model regresi yang bagus yaitu ketika terjadi Homoskedastisitas (Ghozali, 2015).

Uji Mutikolenaritas

Uji multikolenaritas yakni terdapatnya hubungan linier independen di model regresi yang memiliki tujuan guna melihat apakah di model regresi terdahat hubungan diantara variabel bebas. Model regresi yang bagus sebaiknya tak ada hubungan antara variabel independen. Uji multikolenaritas dilaksanakan dengan mengamati tolerance value dan VIF. Apabila nilai VIF < 10 / nilai tolerance $\geq 0.10$ artinya terbebas multikolenaritas, dan sebaliknya (Ghozali, 2015). 


\section{Uji Autokorelasi}

Uji ini mempunyai tujuan guna mendeteksi apakah di model regresi linier data hubungan diantara kekeliruan pengganggu di periode t-I. Penelitian memakai uji Durbin-Watson dimana dinyatakan lolod jika DW antara nilai DU serta 4-DU (Ghozali, 2015).

\subsubsection{Uji Hipotesis}

\subsubsection{Analisis Regresi Linier Berganda}

Regresi berganda dipakai guna melihat adanya korelasi diantara 2 variabel independen ataupun lebih dengan suatu variabel dengan estimasi mean variabel depeden berdasar nilai variabel independen yang dilihat (Nurtantiono, 2020).

Formula Regresi Berganda yakni:

$$
Y=\alpha+\beta_{1} X_{1}+\beta_{2} X_{2}+\beta_{3} X_{2}+\beta_{4} X_{4+} \varepsilon
$$

$\mathrm{Y} \quad=$ Kepatuhan wajib pajak bangunan serta bumi

$\alpha \quad=$ Konstanta

$\beta=$ Koefisien Regresi

$\mathrm{X}_{1,2,3,4, \text { dst }}=$ Pendapatan, sosialisasi, kesadaran, sanksi

$\varepsilon=$ Error

\subsubsection{Koefisien Determinan Berganda $\left(R^{2}\right)$}

Koefisien determinan menunjukkan sebesar apa kontribusi variabel independen pada variabel dependen bisa diamati melalui nilai $R$ Square ataupun Adjusted $R$ Square. Nilai koefisien determinan adalah antaranol serta 1 . Jika $\mathrm{R}^{2}$ nilai kecil maka kompetensi variabel bebas untuk menerangkan variabel terikat sangat terbatas. Nilai yang dekat dengan 1 artinya varibael independennya memberi hamper seluruh informasi yang diperlukan guna mengetahui variabel terikat (Ghozali, 2015).

\subsubsection{Uji $F$}

Uji hini memakai statistik $F$ memiliki kriteria penentuan keputusan secara melakukan perbandingan antara nilai $F$ hasil perhitungan serta nilai $F$ berdasar tabel. Apabila nikai $F$ hitung melebihi nilai $\mathrm{F}$ tabel, Hipotesis nol tidak diterima serta menerima Hipotesis Alternative (Ghozali, 2015).

\subsubsection{Uji T}

Uji ini dilaksanakan secara melakukan perbandingan antara nilai statistik t apakah lebih tinggi titik krisis menurut tabel. Kita tidak menolak hipotesis alternative yang memaparkan yakni sebuah variabel bebas dengan cara individual memberi pengaruh pada variabel terikat. (Ghozali, 2015). 


\section{Hasil dan Pembahasan}

\subsection{Hasil Uji Validitas}

Tabel 4.1

Hasil Uji Validitas Pendapatan Wajib Pajak

No. Butir

Pertanyaan

Correleated item-Total R Tabel
Corelation

Keterangan

$\begin{array}{lll}0.296 & 0.208 & \text { Valid } \\ 0.390 & 0.208 & \text { Valid } \\ 0.301 & 0.208 & \text { Valid } \\ 0.477 & 0.208 & \text { Valid } \\ 0.345 & 0.208 & \text { Valid } \\ 0.413 & 0.208 & \text { Valid }\end{array}$

Sumber: Output SPSS Version 22.0 (Data Diolah, 2021)

Tabel 2 memperlihatkan variabel pendapatan wajib pajak memiliki kriteria sah bagi seluruh pertanyaan bernilai $r$ hitung diatas nilai $r$ tabel. Artinya pernyataan di variable pendapatan wajib pajak dianggap sah.

\section{Tabel 4.2}

Hasil Uji Validitas Sosialisasi Perpajakan

\begin{tabular}{cccc}
$\begin{array}{c}\text { No. Butir } \\
\text { Pertanyaan }\end{array}$ & $\begin{array}{c}\text { Correleated item-Total } \\
\text { Corelation }\end{array}$ & R Tabel & Keterangan \\
$\mathbf{1}$ & 0.290 & 0.208 & Valid \\
$\mathbf{2}$ & 0.308 & 0.208 & Valid \\
$\mathbf{3}$ & 0.304 & 0.208 & Valid \\
$\mathbf{4}$ & 0.414 & 0.208 & Valid \\
$\mathbf{5}$ & 0.526 & 0.208 & Valid \\
$\mathbf{6}$ & 0.307 & 0.208 & Valid \\
$\mathbf{7}$ & 0.470 & 0.208 & Valid \\
\hline
\end{tabular}

Sumber: Output SPSS Version 22.0 (Data Diolah, 2021)

Tabel 3 membuktikan variabel sosialisasi perpajakan memiliki kriteria sah bagi seluruh pertanyaan dengan nilai $r$ hitung diatas nilai $r$ tabel. Artinya pernyataan di variabel sosialisasi perpajakan dianggap tepat.

Tabel 4.3

Hasil Uji Validitas Kesadaran Wajib Pajak

No. Butir

Pertanyaan 1

2

3

4
Correleated item-Total Corelation

$\begin{array}{ll}0.572 & 0.208 \\ 0.444 & 0.208 \\ 0.535 & 0.208 \\ 0.637 & 0.208\end{array}$

\section{Keterangan}

Valid

Valid

Valid

Valid

Sumber: Output SPSS Version 22.0 (Data Diolah, 2021)

Tabel 4 membuktikan variabel kesadaran wajib pajak memiliki kriteria sah bagi seluruh pertanyaan bernilai $r$ hitung diatas nilai $r$ tabel. Artinya pernyataan dalam variabel kesadaran wajib pajak dianggap sah. 
Tabel 4.4

No. Butir

Pertanyaan

1

3

4

5

6

7

Hasil Uji Validitas Sanksi Perpajakan

\section{Correleated item-Total \\ R Tabel} Corelation

0.597
0.598
0.333
0.516
0.673
0.308
0.528

0.208

0.208

0.208

0.208

0.208

0.208

0.208

\section{Keterangan}

Valid

Valid

Valid

Valid

Valid

Valid

Valid

Sumber: Output SPSS Version 22.0 (Data Diolah, 2021)

Tabel 5 membuktikan variabel sanksi perpajakan berkriteria sah bagi seluruh pertanyaan bernilai $r$ hitung diatas nilai $r$ tabel. Artinya pernyataan dalam variabel sanksi perpajakan dianggap sah.

\section{Tabel 4.5}

Hasil Uji Validitas Kepatuhan Wajib Pajak

No. Butir

Pertanyaan

Correleated item-Total R Tabel
Corelation

Keterangan$$
0.564
$$

0.682

0.208

0.208

0.208

0.208

0.642

0.530

0.208

0.208

0.528

0.553

0.208

0.208

Sumber: Output SPSS Version 22.0 (Data Diolah, 2021)

Tabel 6 membuktikan variabel kepatuhan wajib pajak berkriteria valid bagi seluruh pertanyaan bernilai $r$ hitung diatas nilai $r$ tabel. Artinya pernyataan di variabel kepatuhan wajib pajak dinyatakan valid.

\subsection{Hasil Uji Reliabilitas}

$$
\begin{gathered}
\multicolumn{1}{c}{\text { Variabel }} \\
\text { Kepatuhan Wajib Pajak (Y) } \\
\text { Pendapatan Wajib Pajak (X1) }
\end{gathered}
$$

Sosialisasi Perpajakan (X2) Kesadaran Wajib Pajak (X3)

Sanksi Perpajakan (X4)
Tabel 4.6 Hasil Uji Reliabilitas Cronbach' Alpha 0.856 0.611 Reliabe Reliabel Reliabel

Reliabel Reliabel

Reliabel

Tabel 7 membuktikan variabel kepatuhan wajib pajak, pendapatan wajib pajak, sosialisai perpajakan, kesadaran wajib pajak, serta sanksi perpajakan memiliki hasil Cronbach' Alpha $>0.60$. maka variabel tersebut dinyatakann reliabel. 


\subsection{Uji Hipotesis}

4.4.1. Regeresi Linier Berganda

\begin{tabular}{|c|c|c|c|c|c|c|}
\hline \multirow{3}{*}{ Model } & \multicolumn{6}{|c|}{$\begin{array}{c}\text { Tabel } 4.11 \\
\text { Hasil Uji Regresi Linier Berganda } \\
\text { Coefficients }\end{array}$} \\
\hline & & \multicolumn{2}{|c|}{$\begin{array}{l}\text { Unstandardized } \\
\text { Coefficients }\end{array}$} & \multirow{2}{*}{$\begin{array}{c}\text { Standardize } \\
\mathbf{d} \\
\text { Coefficient } \\
\mathbf{s} \\
\text { Beta }\end{array}$} & \multirow[t]{2}{*}{$t$} & \multirow[t]{2}{*}{ Sig. } \\
\hline & & & 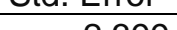 & & & \\
\hline \multirow[t]{4}{*}{1} & $\begin{array}{l}\text { (Constant) } \\
\text { PENDAPAT } \\
\text { AN }\end{array}$ & $\begin{array}{r}5.732 \\
.228\end{array}$ & $\begin{array}{r}2.399 \\
.073\end{array}$ & 223 & $\begin{array}{l}2.389 \\
3.132\end{array}$ & $\begin{array}{l}.019 \\
.002\end{array}$ \\
\hline & $\begin{array}{l}\text { SOSIALISA } \\
\text { SI }\end{array}$ & -.113 & .081 & -.103 & -1.406 & .163 \\
\hline & $\begin{array}{l}\text { KESADARA } \\
\mathrm{N}\end{array}$ & 1.063 & .176 & .557 & 6.028 & .000 \\
\hline & SANKSI & .313 & .107 & .264 & 2.929 & .004 \\
\hline
\end{tabular}

a. Dependent Variable: KEPATUHAN

Sumber: Output SPSS Version 22.0 (Data Diolah, 2021)

Tabel tersebut menunjukkan persamaan regresi linier:

\section{$\mathrm{Y}=5.7320 .228 \mathrm{X} 1+-0.113 \mathrm{X} 2+1.063 \mathrm{X} 3+0.313 \mathrm{X} 4+\mathrm{e}$}

Berdasar hasil persamaan regresi linier berganda itu, bisa dijelaskan bahwa :

I. Nilai konstanta sejumlah 5.732, artinya bila tidak ada variabel sanksi pajak, sosialisasi perpajakan, kesadaran wajib pajak, serta pendapatan wajib pajak. Maka kepatuhan wajib pajak membayar PBB sebesar 5.732.

II. Nilai koefisien regresi variabel pendapatan wajib pajak sejumlah 0.228 yang memaparkan pendapatan wajib pajak bertambah 1 persen, artinya kepatuhan wajib pajak $(\mathrm{Y})$ meningkat sejumlah 0.228

III. Nilai koefisien regresi variabel sosialisai perpajakan sejumlah -0.113 dan bertanda negatif yang menyatakan sosialisasi perpajakan baik satu persen, artinya kepatuhan wajib pajak turun sejumlah -0.113 .

IV. Nilai koefisien regresi variabel kesadaran wajib pajak sejumlah 1.063 yang menyebutkan kesadaran wajib pajak meningkat 1 persen, artinya kepatuhan wajib pajak meningkat sejumlah 1.063 .

V. Nilai koefisien regresi variabel sanksi perpajakan sejumlah 0.313 yang menyebutkan sanksi perpajakan naik 1 persen, artinya kepatuhan wajib pajak $(Y)$ bertambah sejumlah $-0.313$.

\subsubsection{Koefisien Determinasi (R2)}

Hasil uji statistik regresi linier berganda, nilai Adjusted $R$ Square yakni sejumlah 0.647. hal itu artinya kompetensi variabel bebas untuk menguraikan variabel terikat yakni sejumlah $64,7 \%$. 
Tabel 4.12

Hasil Uji Koefisien Determinasi (R2)

\begin{tabular}{|c|c|c|}
\hline $\begin{array}{c}\text { Mod } \\
\text { el }\end{array}$ & $\mathbf{R}$ & $\begin{array}{c}\mathbf{R} \\
\text { Square }\end{array}$ \\
\hline
\end{tabular}
Model Summaryb

$1 \quad .814^{\mathrm{a}} \quad .663 \quad 647$

Std. Error of the Estimate

a. Predictors: (Constant), SANKSI, PENDAPATAN, SOSIALISASI, KESADARAN

b. Dependent Variable: KEPATUHAN

Sumber: Output SPSS Version 22.0 (Data Diolah, 2021)

\subsubsection{Uji $F$}

\section{Tabel 4.13}

Hasil Uji F

Model

1

\section{Regression}

Residual

Total

ANOVA $^{a}$

\section{Sum of Squares}

872.366

443.920 1316.286

df

Mean

218.092

5.162 2.272

a. Dependent Variable: KEPATUHAN

Berdasar tabel analisis regresi $\mathrm{F}$ hitung $=42.251>\mathrm{F}$ Tabel 2.47 memiliki tingkat signifkan yakni $0.000<0.05$, bisa ditarik kesimpulan yakni salah satu variabel independen yang diteliti pada penelitian ini setidaknya memiliki pengaruh signifikan terhadap variabel dependen yang diteliti. Oleh karenanya, hasil uji dilanjutkan dengan melakukan analisis terhadap uji-t.

\subsubsection{Uji $t$}

Model

$1 \quad$ (Constant)

PENDAPAT

AN

SOSIALISA

SI

KESADARA

$\mathrm{N}$

SANKSI
Tabel 4.14

Hasil Uji Parsial T

Coefficients $^{a}$

Unstandardized

Coefficients

B

5.732

.228

Std. Error

2.399

.073

.081

$-.113$

.176

1.063

.176

.107

Standardiz
ed
Coefficient

$\mathbf{s}$

a. Dependent Variable: KEPATUHAN

Sumber: Output SPSS Version 22.0 (Data Diolah, 2021)

H1: Penghasilan Wajib Pajak memberi pengaruh signifikan atas Kepatuhan Pembayaran Pajak Bumi serta Bangunan

Berdasar hasil uji signifikan parsial, variabel penghasilan wajib pajak memiliki tingkat signifikan sejumlah 0.02 yang jika dilakukan perbandingan dengan tingkat kekeliruan yang 
ditetapkan yakni sejumlah $5 \%$, nilai signifikan variabel pendapatan wajib pajak dibawah tingkat kekeliruan. Maka bisa ditarik kesimpulan yakni penghasilan wajib pajak memberi pengaruh signifikan atas kepatuhan pembayaran pajak bumi serta bangunan yakni besar kecilnya penghasilan akan mempengaruhi wajib pajak dalam melaksanakan kewajibannya. Hasil tersebut sejalan berdasarkan penelitian yang dilaksanakan Nadwatul Khoiroh, 2017 mengungkapkan pendapatan wajib pajak memberi pengaruh pada kepatuhan pembayaran pajak bumi serta bangunan. Jadi H1 diterima.

H2: Sosialisai Perpajakan memberi pengaruh signifikan pada Kepatuhan Pembayaran Pajak Bumi serta Bangunan

Berdasarkan hasil uji signifikan parsial, variabel sosialisasi perpajakan memiliki tingkat signifikan sejumlah 0.163 daripada dengan tingkat kekeliruan yang ditetapkan yakni sejumlah $5 \%$, maka nilai signifikan variabel pendapatan wajib pajak lebih besar dari derajat kesalahan. Bisa diambil kesimpulan yakni sosialisasi perpajakan tidak memberi pengaruh signifikan pada kepatuhan pembayaran pajak bangunan serta bumi karena sosialisasi perpajakan menjadi hal yang penting untuk memupuk pemahaman mereka mengenai pajak, tetapi di Dukuh Pengkol sosialisasi mengenai pajak bumi serta bangunan melalu pemerintah maupun spanduk tidak ada. Hasil itu sejalan berdasarkan penelitian yang dilaksanakan Nadwatul Khoiroh, 2017 dalam penelitiannya memaparkan sosialisasi perpajakan tidak memberi pengaruh pada kepatuhan pembayaran pajak bumi serta bangunan. Jadi $\mathrm{H} 1$ ditolak.

H3: Kesadaran Wajib Pajak memberi pengaruh signifikan pada Kepatuhan Pembayaran Pajak Bumi serta Bangunan

Berdasar hasil uji signifikan parsial, variabel kesadaran wajib pajak mempunyai tingkat signifikan sejumlah 0.00 daripada dengan tingkat kekeliruan yang ditetapkan yakni sejumlah $5 \%$, nilai signifikan variabel pendapatan wajib pajak dibawah tingkat kekeliruan. Bisa disimpulkan yakni kesadaran wajib pajak memberi pengaruh signifikan atas kepatuhan pembayaran pajak bangunan serta bumi karena kesadaran timbul melalui diri wajib pajak tersebut. Ketika masyarakat tidak mempunyai kesadaran untuk membayar maka akan mempengaruhi kepatuhan pembayaran pajak tersebut Hasil tersebut tidak sesuai berdasarkan penelitian yang dilaksanakan Febriani Ramdhani Juwiyanti, 2017 yang menguraikan kesadaran wajib pajak tidak memberi pengaruh atas kepatuhan pembayaran pajak bangunan serta bumi. Jadi $\mathrm{H} 1$ diterima.

H4: Sanksi Perpajakan memberi pengaruh signifikan pada Kepatuhan Pembayaran

\section{Pajak Bumi serta Bangunan}

Berdasarkan hasil uji signifikan parsial, variabel sanksi perpajakan memiliki tingkat signifikan sejumlah 0.04 daripada dengan tingkat kekeliruan yang ditetapkan yakni sejumlah $5 \%$, nilai signifikan variabel sanksi perpajakan dibawah tingkat kekeliruan. Maka bisa ditarik 
kesimpulan yakni sanksi perpajakan pajak memberi pengaruh signifikan pada kepatuhan pembayaran pajak bumi serta bangunan, karena sanksi administrasi dan pidana akan menjadikan masyarakat patuh dalam membayar pajak. Hasil tersebut selaras berdasarkan penelitian yang dilaksanakan Nadwatul Khoiroh, 2017 yang menyebutkan sanksi perpajakan memberi pengaruh pada kepatuhan pembayaran pajak bumi dan bangunan. Jadi $\mathrm{H} 1$ diterima.

\section{Kesimpulan, Keterbatasan, dan Saran}

Berdasarkan penelitian dan olah data yang sudah dilaksanakan, bisa disimpulkan yakni penelitian bertujuan untuk melihat faktor apa saja yang memberi pengaruh pada masyarakat untuk memenuhi kewajiban pembayaran pajak bangunan serta bumi. Yang paling berpengaruh dalam kepatuhan pembayaran pajak bangunan serta bumi adalah kesadaran wajib pajak, dimana kesadaran timbul melalui diri wajib pajak tersebut. Ketika masyarakat tidak mempunyai kesadaran untuk membayar maka akan mempengaruhi kepatuhan pembayaran pajak tersebut. Selain itu penelitian ini menunjukkan kepatuhan pembayaran pajak juga dipengaruhi oleh pendapatan dan sanksi dimana wajib pajak akan lebih mudah membayar pajak ketika mempunyai uang dan masyarakat juga takut terhadap keberadaan sanksi pajak. Keterbatasan pada penelitian yakni hanya berada di lingkup Dukuh saja, sehingga untuk penelitian selanjutnya lebih memperluas lingkup objek pajaknya. Saran bagi penelitian selanjutnya, dikarenakan saat ini sedang pandemi Covid maka penulis tidak dapat terjun langsung dan mendampingi masyarakat dalam pengisian kuisoner yang disebarkan penulis melalui google form sehingga banyak masyarakat yang lalai dalam mengisi dan mengirimkan kuisionernya. Dengan demikian, untuk penelitian selanjutnya dapat dimaksimalkan dalam terjun langsung dan mendampingi masyarakat dalam pengisian kuisioner agar segera kembali dan mempermudah penelitian.

\section{Daftar Pustaka}

Badan Pengelolaan Keuangan Daerah Kabupaten Klaten (2020). Daftar Himpunan Ketetapan Pajak \& Pembayaran (DHKP) Pajak Bumi dan Bangunan. Klaten. BKD Kabupaten Klaten.

Dr. Samsuar, M. (2019). Atribusi. Jurnal Network Media, 2(1), 65-69.

Ghozali, I. (2015). Aplikasi Analisis Multivariate dengan Program IBM SPSS. 23. Semarang: Universitas Diponegoro.

Humas. (2020). bpjskesehatan.go.id. Diperoleh dari https://bpjskesehatan.go.id/bpjs/index.php/pages/detail/2014/11. 
Isawati, T. (2017). Pengaruh Tingkat Pendapatan, Pengetahuan Pajak, Pelayanan Pajak, serta Sanksi Pajak Terhadap Kepatuhan Wajib Pajak Dalam Membayar Pajak Bumi dan Bangunan. Ekonomia, 5(3).

Jati, I. G. (2016). Pengaruh Sikap, Kesadaran Wajib Pajak dan Pengetahuan Perpajakan pada Kepatuhan Membayar Pajak Bumi Dan Bangunan. E-Jurnal Akuntansi Universitas Udayana, 1510-1535.

Juwiyanti, F. R. (2017). Pengaruh Pengetahuan Perpajakan, Kesadaran Wajib Pajak, Norma Sosial, Kepercayaan Pada Pemerintah dan Sanksi Pajak Terhadap Kepatuhan Wajib Pajak Dalam Melakukan Pembayaran Pajak Bumi dan Bangunan (Studi Pada Wajib Pajak Bumi dan Bangunan Kecamatan Colomadu. Jurnal Riset Manajemen, 6(1).

Khoiroh, N., \& Purwanto, I. (2017). Pengaruh Sanksi, Sosialisasi, dan Pendapatan Wajib Pajak Terhadap Kepatuhan Wajib Pajak Dalam Membayar Pajak Bumi Dan Bangunan Di Desa Gandaria. Jurusan Pendidikan IImu Pengetahuan Sosial, Universitas Islam Negeri Syarif Hidayatulah.

Mardiasmo. (2016). Pepajakan Edisi Terbaru 2016. Yogyakarta: Andi Yogyakarta.

Mardiasmo. (2019). Perpajakan Edisi Terbaru 2019. Yogyakarta: Andi Yogyakarta.

Nurtantiono, A. (2020). Analisis Regresi Kasus dan Analisis dengan SPSS. Surakarta: STIE Surakarta.

Pendapatan. Dalam Kamus Besar Bahasa Indonesia (KBBI) Online, Diperoleh dari https://kbbi.kemdikbud.go.id/

Prakoso, T. S. (2020). Capaian PBB Lebihi Target, Pemkab Klaten Bebaskan Denda Keterlambatan. Solopos.Com. Diperoleh dari https://www.solopos.com/capaian-pbb-lebihitarget-pemkab-klaten-bebaskan-denda-keterlambatan-1086153.

Prananjaya, K. P., \& Narsa, N. P. D. R. H. (2019). Obedience Pressure and Tax Sanction: An Experimental Study on Tax Compliance. Jurnal Akuntansi dan Keuangan, 21(2), 68-81.

Purenda, A. (2019). BPKD Terus Optimalkan Pendapatan Pajak Daerah. Radarsolo.jawapos.com. Diperoleh dari https://radarsolo.jawapos.com/read/2019/09/18/156396/bpkd-terus-optimalkanpendapatan-pajak-daerah.

Purnaditya, R. R, dan Rohman, A. (2015). Pengaruh Pemahaman Pajak, Kualias Pelayanan dan Sanksi Pajak Terhadap Kepatuhan Pajak (Studi Empiris pada WP OP yang Melakukan Kegiatan Usaha di KPP Pratama Semarang Candisari. Diponegro Journal of Accounting 4(4) 1-15.

Purnaditya, R. R., \& Rohman, A. (2015). Pengaruh Pemahaman Pajak, Kualitas Pelayanan, Dan Sanksi Pajak Terhadap Kepatuhan Pajak. Jurnal Network Media, 4(4).

Rahayu, P. (2019). Perpajakan Edisi Pertama (1st ed.). Sidoarjo: Indomedia Pustaka.

Rahman, A. (2018). Pengaruh Kesadaran Wajib Pajak, Tingkat Pendidikan, dan Pendapatan Terhadap Kepatuhan Membayar Pajak Bumi dan Bangunan. Jurnal Akuntansi, 6(1). 
Republik Indonesia. Undang-Undang No. 16 Tahun 2009 tentang Ketentuan Umum dan Tata Cara Perpajakan. Jakarta: Sekretariat Negara.

Republik Indonesia. Undang-Undang No. 20 Tahun 2009 tentang Pajak Daerah dan Retribusi Daerah. Jakarta: Sekretariat Negara.

Saputra, R. (2015). Pengaruh Sanksi, Kesadaran Perpajakan, Dan Kualitas Pelayanan Wajib Pajak Terhadap Kepatuhan Wajib Pajak Bumi Dan Bangunan (Studi Empiris Pada Wajib Pajak Kabupaten Pasaman). Jurnal Akuntansi, 3(1).

Setyowati, Y., \& Yushita, A. N. (2017). Pengaruh Pengetahuan Perpajakan, Sanksi Pajak dan Kesadaran Wajib Pajak Terhadap Kepatuhan Wajib Pajak Orang Pribadi Dalam Membayar Pajak Bumi Dan Bangunan Di Desa Kalidengen, Kecamatan Temon, Kabupaten Kulon Progo Tahun 2014. Profita, 8, 1-21.

Siregar, O. K., \& Rahayu, S. A. (2019). The Influence Of Sanctions, Quality Of Service And Socialization On Compliance Of Pay Tax And Buildings In Pantai Gemi Village In Stabat Langkat. Accounting and Bussines Journal, 4(3), 57-71. http://marefateadyan.nashriyat.ir/node/150

Susanto, H. (2012). Membangun Kesadaran dan Kepedulian Sukarela Wajib Pajak. Diperoleh dari https://www.pajak.go.id/id/artikel/membangun-kesadaran-dan-kepedulian-sukarelawajib-pajak.

Syukra, R. (2020). Bulog-Kemensos Luncurkan Program Bansos Beras untuk 10 Juta Keluarga Artikel ini telah tayang di Investor.id dengan judul "Bulog-Kemensos Luncurkan Program Bansos Beras untuk 10 Juta Keluarga. Beritasatumedia.com. Diperoleh dari https://investor.id/business/bulogkemensos-luncurkan-program-bansos-beras-untuk-10juta-keluarga

Widiyanti, D. R., \& Prananditya, A. (2018). Pengaruh Sosialisasi, Sanksi Dan Pemahaman Prosedur Perpajakan Terhadap Kepatuhan Wajib Pajak Bumi Dan Bangunan (Pbb) Di Kecamatan Bergas Kabupaten Semarang. Jurnal Akuntansi. 